\title{
Frequência de anticorpos contra o herpesvírus bovino 1 (BoHV-1) em bubalinos (Bubalus bubalis) de corte não vacinados provenientes do município de Guaraqueçaba, Paraná
}

Rodrigo Azambuja Machado de Oliveira ${ }^{[a]}$, Juliana Fritzen ${ }^{[b]}$, Amauri Alcindo Alfieri ${ }^{[b]}$, Júlio Augusto Naylor Lisbôa ${ }^{[b] ;}$, Ivan Roque de Barros Filho ${ }^{[c]}$

\footnotetext{
[a] Centro de Ensino Superior dos Campos Gerais (CESCAGE), Ponta Grossa, PR, Brasil

[b] Programa de Pós-gradução em Ciência Animal, Universidade Estadual de Londrina (UEL), Londrina, PR, Brasil

[c] Docente do curso de Medicina Veterinária, Universidade Federal do Paraná (UFPR), Curitiba, PR, Brasil
}

*Autor correspondente
e-mail: janlisboa@uel.br

Resumo

As infecções herpéticas provenientes do herpesvirus bovino 1 (BoHV-1) são de grande importância devido a elevadas taxas de dispersão no ambiente. Os bovinos são hospedeiros naturais do BoHV-1, porém infecções pelo vírus têm sido relatadas em outras espécies de ruminantes, inclusive bubalinos. 0 presente trabalho teve como objetivo determinar a frequência de amostras frente ao BoHV-1 em bubalinos de corte não vacinados, por meio da técnica de virusneutralização (VN). Para isso foram coletadas amostras de soro sanguíneo de animais oriundos do município de Guaraqueçaba, com posterior encaminhamento para o Laboratório de Virologia Animal da Universidade Estadual de Londrina (UEL). Foram examinadas 20 amostras de sangue provenientes de bubalinos de corte criados em regime extensivo, em dezembro de 2016. Os animais eram machos e fêmeas de diferentes categorias, com idade entre 6 e 8 meses, não vacinados contra BoHV-1. A coleta de amostras sanguíneas deu-se através da venopunção da veia jugular. As amostras foram mantidas refrigeradas em caixas isotérmicas para posterior processamento laboratorial, com a finalidade de obtenção de soro sanguíneo. Posteriormente, o material foi novamente armazenado em tubos a vácuo, mantidos congelados e, finalmente, encaminhados para o Laboratório de Virologia Animal da Universidade Estadual de Londrina (UEL), onde foi feita a leitura e processamento das amostras para o teste de VN. Das amostras sorológicas avaliadas, 16/20 $(80 \%)$ geraram anticorpos neutralizantes frente ao BoHV-1. As amostras restantes 4/20 (20\%) não foram reagentes. 0 teste de $\mathrm{VN}$ é amplamente usado em inquéritos epidemiológicos, sendo considerado um teste padrão para detecção de anticorpos contra o BoHV-1 em ruminantes. No Paraná, estudo pioneiro realizado por Oliveira (2013), utilizando a Reação em cadeia da Polimerase (PCR) para a identificação do BohV-1 em amostras 
de gânglio trigêmeo em bovinos de corte de todas as mesorregiões do estado, evidenciou a presença do genoma viral em 14,2\% dos bovinos amostrados. Contudo, a análise sorológica realizada no presente estudo evidencia uma elevada circulação do BoHV-1 em bubalinos criados na mesorregião de Curitiba. Ademais, embora tratem de métodos diagnósticos distintos, o presente estudo comprova a infecção herpética interespecífica em bubalinos criados na região centro oriental do estado. Estudo pioneiro no estado sobre a soroprevalência do BoHV-1 em amostras bubalinas nos municípios de Antonina e Doutor Ulysses evidenciaram uma positividade de $90 \%(18 / 20)$ dos animais. Complementarmente, os dados do presente estudos corroboram com o estudo soroepidemiológico conduzido em bubalinos criados na mesorregião de Ponta Grossa, em que 78,5\% dos animais foram considerados positivos. A presença do BoHV-1 em bubalinos na região amostrada mostrou-se elevada, e os dados são fundamentais para a adoção de medidas mitigatórias para o controle do agente. 